\title{
Yields and Persistency of Lactation in Friesian and Jersey Cows Milked Once Daily
}

\author{
R. E. Hickson, ${ }^{\star 1}$ N. Lopez-Villalobos, ${ }^{*}$ D. E. Dalley, $†$ D. A. Clark, $†$ and C. W. Holmes ${ }^{\star}$ \\ ${ }^{*}$ Institute of Veterinary, Animal and Biomedical Sciences, Massey University, Private Bag 11,222, New Zealand \\ †Dexcel Limited, Private Bag 3,221, Hamilton, New Zealand
}

\section{ABSTRACT}

Effects of milking cows once daily throughout lactation at high stocking rates (17\% more cows/ha than for those milked twice daily) were studied in 2 Friesian and 2 Jersey herds during 3 lactations. Cows were allocated to 2 herds within breed and were milked either once or twice daily, based on age, genetic merit, and previous performance. Cows remained in their original herd and were milked at the same milking frequency during all lactations. Culled cows (20\% per year) were replaced by 2 -yr-old heifers. Yields of milk, lactose, protein, and fat were measured every $2 \mathrm{wk}$ by commercial herd test. Cubic splines ( 5 knots) were used to approximate the lactation curve for each cow-yr to provide estimates of performance for each day of lactation. Yields of milk were greater for Friesian and Jersey cows milked twice daily $(4,751 \pm 89$ and $3,067 \pm 81 \mathrm{~kg} / \mathrm{cow})$ than for cows milked once daily (3,329 \pm 80 and 2,431 $\pm 75 \mathrm{~kg} / \mathrm{cow}$ ), respectively. Cows milked once daily had lesser total and peak yields of milk, lactose, protein, and fat than cows milked twice daily. Friesians had greater total and peak yields than Jerseys. Peak production for all milk components occurred earlier in lactation for cows milked once daily than twice daily (d 24 to 39 vs. 32 to 44). Three measures of persistency of lactation were considered for each cow with 2 measures (Pers1 and Pers2) indicating that cows milked twice daily had better persistency than those milked once daily. Ranking of herds in persistency tended to match the ranking based on total yields. Measures of persistency (Pers1 and Pers2) were positively related to total yield in the Jerseys milked once daily and negatively related to peak yield in the Friesians. The third persistency measure (Pers3) ranked once-daily Jerseys first and twice-daily Friesians last, and was negatively correlated with total yield in the Friesian herds and negatively correlated with peak yield in all herds. For most

Received August 16, 2005.

Accepted December 21, 2005.

${ }^{1}$ Corresponding author: r.hickson@massey.ac.nz performance measures, cows milked twice daily had better total yields and persistency than cows milked once daily.

Key words: persistency, once daily milking, milking frequency

\section{INTRODUCTION}

Milking frequency is an important contributor to costs of production in the pastoral systems of the New Zealand dairy industry. Milking cows once daily can reduce farm expenses, particularly labor costs and milking parlor consumables. Furthermore, it may increase quality of life and improve health and welfare of cows, primarily through increased body condition and potentially, decreased lameness because of less walking (Woolford et al., 1985; Carruthers et al., 1989; Davis et al., 1998, 1999). Cows milked once daily carry a greater volume of milk in their udder, but no differences exist in the incidence of IMI between cows milked once and twice daily (Lacy-Hulbert et al., 2005). The major disadvantage of once-daily milking is reduced milk production. Losses reported in previous experiments ranged from 7 to $38 \%$ for part-lactation periods of once-daily milking (Davis et al., 1998) and losses from full lactations ranged from 22 to $35 \%$ in New Zealand studies (Holmes et al., 1992; Tong et al., 2002). Wide variation in production losses of individual cows (compared with those of identical twins milked twice daily or with their previous twice-daily production) has been observed, ranging from 0 to $47 \%$ in part-lactation studies (Claesson et al., 1959; Carruthers et al., 1989), and from 5 to $85 \%$ in full-lactation studies (Claesson et al., 1959; Holmes et al., 1992).

Dependence on pasture as a feed source in New Zealand has contributed to a concentrated national calving period, causing the period of peak production to coincide for many cows. Consequently, supply to milk processors varies considerably during the year, from large quantities during the spring peak to very low quantities during winter. This creates inefficiencies in the milk-processing system, so methods of distributing the national milk yield more evenly throughout the year are of interest to both dairy producers and milk 
processors. Once-daily milking has been identified as a method of reducing peak yields while having little effect on production during later lactation relative to twice-daily herds (Harding et al., 1990). Other studies, however, have identified a greater difference in production between once- and twice-daily herds during late lactation than in early lactation (Claesson et al., 1959), indicating that the persistency of cows milked once daily is less than that of cows milked twice daily. Harding et al. (2002) observed that some cows dried off very early in lactation when milked once daily, indicating that persistency of lactation may be a problem in oncedaily milking systems. Persistency of lactation is a measure of the rate at which milk production declines after peak yield (Turner, 1925; Togashi and Lin, 2003) and can be quantified by using a variety of measures. Persistency of lactation has not been extensively studied in the once-daily system, but because of the smaller peak yields, and the early drying off of some cows, persistency of lactation may be an important determinant of the total yields of cows milked once daily.

The objectives of this study were to identify effects of once-daily milking at a greater stocking rate in Friesian and Jersey herds on 1) total yields, 2) persistency of lactation, and 3) correlations between persistency of lactation and total and peak yields, using 3 different measures of persistency.

\section{MATERIALS AND METHODS}

\section{Animals and Management Conditions}

Four herds were milked during 3 consecutive lactations. The herds consisted of Friesian and Jersey cows, with 1 herd of each breed milked once daily and the other twice daily. The 4 herds were balanced for age, calving date, live BW, BCS, breeding worth, and milk protein and milk fat production during the previous season. Breeding worth is the official national economic index used to rank cows and bulls according to their genetic potential (inherited by their progeny) to convert 4.5 tonnes of DM into farm profit. Each herd was located on a separate 10-ha pasture, managed according to the decision rules developed by Macdonald and Penno (1998). Dry-off date of cows was determined by their production (if their daily yield fell below $5 \mathrm{~L}$ ) or SCC ( $>400,000$ cells $/ \mathrm{mL}$ in 2 consecutive herd tests). Some cows reached these thresholds earlier than the set dryoff date and consequently, were dried off earlier. Oncedaily herds were stocked at a greater stocking rate (1.17 times more cows/ha) than twice-daily herds to compensate for expected declines in milk yield per cow and feed requirements (Holmes et al., 1992). Herd sizes (numbers of cows calving each year) were as follows: Friesian once daily $(\mathrm{n}=35)$; Friesian twice daily $(\mathrm{n}=$
30); Jersey once daily ( $\mathrm{n}=42$ ); and Jersey twice daily $(\mathrm{n}=35)$.

Once allocated to a herd, each cow remained in that herd until culled. Cows were culled for failing to conceive within the mating period, high SCC, or health problems, with minimal culling based on production. Culls were replaced by 2 -yr-old heifers of the appropriate breed and breeding worth, with the annual replacement rate set at $20 \%$ to ensure that the herds had similar age structures. The number of complete lactation records collected was 100 for the Friesians milked once daily; 85 for the Friesians milked once daily; 119 for the Jerseys milked once daily; and 101 for the Jerseys milked twice daily.

\section{Measurements}

Individual milk yields were recorded automatically at each milking. Milk composition (fat, protein, and lactose) was measured in individual cow samples at biweekly (every $2 \mathrm{wk}$ ) intervals throughout lactation using a Milkoscan 133B milk analyzer (Foss Electric, Hillerød, Denmark), calibrated for different matrix effects of milk from different breeds. The SCC for individual cows was measured every 2 wk using a cell counter (Fossomatic, Foss Electric). Calving date and age were recorded for each cow.

A cubic spline (with 5 knots) was fitted to each lactation of each cow (SAS Inst. Inc., Cary, NC) to provide a continuous lactation curve for milk, lactose, protein, and fat. Daily yields were predicted using these splines for each day from calving to drying off. Total yields, peak yields, and days of peaks were calculated based on these predicted daily yields.

Three measures of persistency were used. The first measure (Pers1) was based on that developed by Turner (1925) and involved dividing the period from peak daily yield to drying off into 7 equal-length periods. Percentage of a previous period of production remaining was calculated for periods 2 to 7 , and the percentages averaged to get Pers1:

$$
\operatorname{Pers} 1=\frac{100 \times \sum_{i=2}^{7} \frac{P_{i}}{P_{i-1}}}{6}
$$

where $P_{\mathrm{i}}=$ total yield in period $i$.

A second measure (Pers2) was based on that used in the Canadian dairy sire evaluation system (Murray and Brand, 2000). The Pers2 was calculated as production $20 \mathrm{~d}$ before dry off divided by peak production and multiplied by 100 to get the percentage value. Day of peak varied for the different milk components and 
among cows, whereas day of dry off varied only among cows.

A third persistency measure (Pers3) was developed by Kamidi (2005), and involved fitting a quadratic polynomial to the cumulative yield of each cow, and finding the deceleration in yield during lactation (the second derivative, $2 \gamma$ ). Kamidi (2005) used the formula [persistency $=100(1+2 \gamma)$ ] to convert the deceleration constant $(\gamma)$ to a percentage measure of persistency. The range of values of $\gamma$ calculated for the cows had a very low variance, which meant that such a large-scale transformation $(\times 100)$ brought the values for persistency into a very small range. Instead, the $\gamma$ values were transformed to give a normal distribution of Pers3, using the equation

$$
\operatorname{Pers} 3=\frac{\gamma_{i}-\bar{\gamma}}{\sigma}
$$

where $\gamma_{i}$ is the $i$ th value of $\gamma, \bar{\gamma}$ is the mean value of $\gamma$, and $\sigma$ is the standard deviation of the $\gamma$ values.

For all persistency measures used, a greater value corresponded to better persistency.

\section{Statistical Analyses}

Yields were normally distributed. Parameters of the lactation curve for each cow were analyzed using PROC MIXED for repeated measures (SAS Institute Inc.). The model included year, breed, and milking frequency as fixed effects, with age, age ${ }^{2}$, and deviation from average calving date fitted as covariates. Interactions between year, breed, and milking frequency were considered. The random effect of cow also was included. Correlations between persistency and yields were calculated using the PROC CORR procedure (SAS Institute Inc.).

\section{RESULTS}

\section{Yields of Milk, Lactose, Protein, and Fat}

Milking frequency had effects $(P \leq 0.05)$ on total yield, peak yield, and day of peak yield for all milk components. Breed affected $(P \leq 0.001)$ total yields and peak yield for all milk components, and day of peak protein and fat yields, whereas breed $\times$ milking frequency interaction $(P \leq 0.05)$ altered total and peak yields of all milk components.

Friesians milked twice daily had the greatest $(P \leq$ $0.05)$ mean total yield per cow for all milk components (Table 1). Jerseys milked once daily had the lowest ( $P$ $\leq 0.05$ ) total yields for all components, although total fat yield was not different from that of Friesians milked once daily. Total yield of Friesians milked once daily did not differ from yield of Jerseys milked twice daily for lactose and protein, but was greater $(P \leq 0.05)$ for milk volume and lesser for fat yield. In addition to the variation in mean yield, the herds differed $(P \leq 0.05)$ in their range of production among cows, with Friesians milked once daily having greater $(P \leq 0.05)$ variations in yield than Friesians milked twice daily (Table 1). The best Friesian cow milked once daily produced almost as much milk and milk components as the best Friesian cow milked twice daily, but the worst Friesian cow milked once daily produced much less milk and milk components than the worst Friesian cow milked twice daily. The range between best and worst cows was similar between the Jersey herds, with the best and worst Jerseys milked once daily producing less than the best and worst Jerseys milked twice daily, respectively.

Mean peak yields per cow were greatest $(P \leq 0.05)$ for the Friesians milked twice daily and smallest $(P$ $\leq 0.05$ ) for the Jerseys milked once daily for all milk components (Table 1). The Friesians milked once daily reached greater $(P \leq 0.05)$ mean peak yields than the Jerseys milked twice daily for milk volume and lactose, but was not different for peak protein yield and was less $(P \leq 0.05)$ for peak fat yield. The once-daily herds reached peak milk yield and peak lactose yield earlier $(P \leq 0.001)$ than the twice-daily herds for both breeds, but this difference was not detected for protein and fat peaks. Peak yields for all milk components were achieved within $5 \mathrm{~d}$ of each other within Friesian herds, but were spread over $12 \mathrm{~d}$ in Jersey herds, with the peak fat yield occurring last.

\section{Persistency of Lactation}

The twice-daily herds had better $(P \leq 0.05)$ persistency of lactation than the once-daily herds for Pers1 and Pers2. Effect of milking frequency differed $(P \leq$ 0.05 ) for all persistency measures, except Pers3 for fat yield. Neither breed nor breed $\times$ milking frequency interaction affected Pers1 or Pers2, but breed affected ( $P$ $\leq 0.05$ ) the Pers3 of milk, lactose, and protein production, for which Jersey herds had better $(P \leq 0.001)$ persistency than Friesian herds. The values of the measures of persistency of lactation are in Table 2.

Correlations between Pers1 or Pers2 and total yield existed ( $P \leq 0.05)$ only for Jerseys milked once daily, whereas correlations between Pers3 and total yield were significant $(P \leq 0.05)$ in all herds, except for Jerseys milked once daily, and in Jerseys milked twice daily for milk and protein (Table 3). No significant effects of breed or milking frequency were detected, with the exception that milking frequency had an effect ( $P$ $\leq 0.05$ ) on the correlation between Pers2 and total yield 
Table 1. Traits of the lactation curve and total yield for milk, lactose, protein, fat production of Friesian and Jersey cows milked once or twice daily ${ }^{1}$

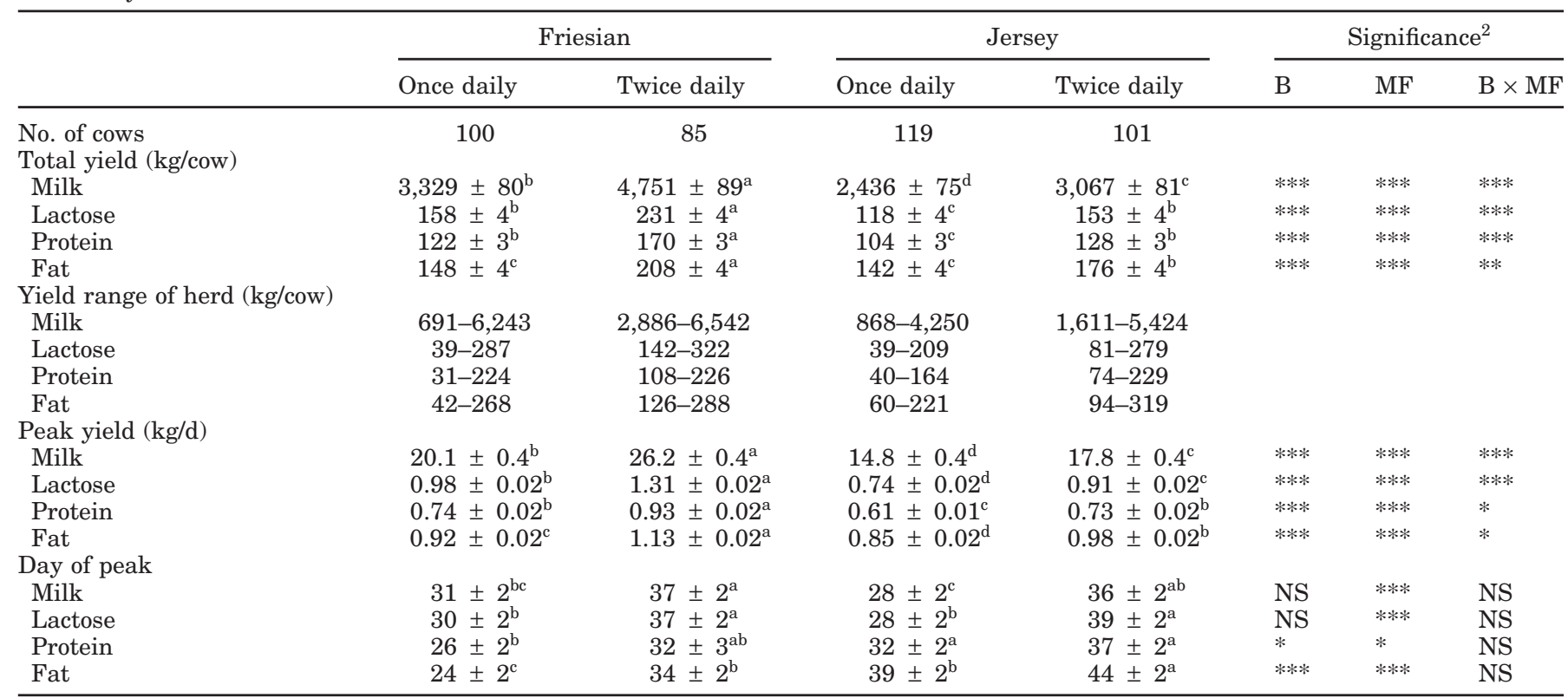

${ }^{\mathrm{a}-\mathrm{d}}$ Values within rows having different superscript letters differ $(P<0.05)$.

${ }^{1}$ Least squares means $\pm \mathrm{SE}$.

${ }^{2} \mathrm{~B}=$ Breed; $\mathrm{MF}=$ milking frequency.

NS $=$ Not significant; ${ }^{*} P<0.05 ;{ }^{* *} P<0.01 ; * * * P<0.001$.

for protein and fat. Correlations were positive for Pers1 and Pers2, but negative for Pers3.

Correlations between peak yield and persistency were negative for all milk components for which the correlation existed $(P \leq 0.05)$. Values of Pers1 and Pers2 were correlated $(P \leq 0.01)$ with peak yield in the Friesian herds, and Pers3 was correlated $(P \leq 0.001)$ with peak yield in all the herds (Table 4). There was no significant effect of breed or milking frequency on any correlations.

Table 2. Three measures of lactation persistency (Pers1, Pers2, and Pers3) for yields of milk, lactose, protein, and fat in Friesian and Jersey cows milked once or twice daily ${ }^{1}$

\begin{tabular}{|c|c|c|c|c|c|c|c|}
\hline & \multicolumn{2}{|c|}{ Friesian } & \multicolumn{2}{|c|}{ Jersey } & \multicolumn{3}{|c|}{ Significance $^{2}$} \\
\hline & Once daily & Twice daily & Once daily & Twice daily & B & $\mathrm{MF}$ & $\mathrm{B} \times \mathrm{MF}$ \\
\hline No. of cows & 100 & 85 & 119 & 101 & & & \\
\hline \multicolumn{8}{|l|}{ Pers1 (\%) } \\
\hline Milk & $80.9 \pm 0.6^{\mathrm{b}}$ & $83.6 \pm 0.6^{\mathrm{a}}$ & $81.0 \pm 0.5^{b}$ & $82.6 \pm 0.6^{\mathrm{a}}$ & NS & $* * *$ & NS \\
\hline Lactose & $80.0 \pm 0.6^{\mathrm{b}}$ & $82.6 \pm 0.7^{\mathrm{a}}$ & $80.1 \pm 0.6^{b}$ & $81.6 \pm 0.6^{\mathrm{ab}}$ & NS & $* *$ & NS \\
\hline Protein & $82.8 \pm 0.6^{b}$ & $84.8 \pm 0.6^{\mathrm{a}}$ & $83.3 \pm 0.5^{\mathrm{ab}}$ & $84.7 \pm 0.6^{\mathrm{a}}$ & NS & $* *$ & NS \\
\hline Fat & $83.0 \pm 0.6^{\mathrm{b}}$ & $85.8 \pm 0.7^{\mathrm{a}}$ & $83.1 \pm 0.6^{\mathrm{b}}$ & $84.8 \pm 0.6^{\mathrm{a}}$ & NS & $* * *$ & NS \\
\hline \multicolumn{8}{|l|}{ Pers2 (\%) } \\
\hline Milk & $35.2 \pm 1.5^{\mathrm{b}}$ & $41.4 \pm 1.7^{\mathrm{a}}$ & $34.7 \pm 1.4^{\mathrm{b}}$ & $38.7 \pm 1.5^{\mathrm{ab}}$ & NS & $* *$ & NS \\
\hline Lactose & $32.9 \pm 1.5^{\mathrm{bc}}$ & $38.1 \pm 1.6^{\mathrm{a}}$ & $32.1 \pm 1.4^{\mathrm{c}}$ & $36.4 \pm 1.5^{\mathrm{ab}}$ & NS & $* *$ & NS \\
\hline Protein & $39.3 \pm 1.6^{\mathrm{b}}$ & $44.2 \pm 1.8^{\mathrm{a}}$ & $40.8 \pm 1.5^{\mathrm{ab}}$ & $44.3 \pm 1.7^{\mathrm{a}}$ & NS & $*$ & NS \\
\hline Fat & $39.2 \pm 1.8^{\mathrm{b}}$ & $47.0 \pm 2.0^{\mathrm{a}}$ & $40.5 \pm 1.7^{\mathrm{b}}$ & $46.3 \pm 1.8^{\mathrm{a}}$ & NS & $* * *$ & NS \\
\hline \multicolumn{8}{|l|}{ Pers3 } \\
\hline Milk & $-0.20 \pm 0.09^{b}$ & $-0.46 \pm 0.10^{\mathrm{b}}$ & $0.45 \pm 0.09^{\mathrm{a}}$ & $0.28 \pm 0.09^{\mathrm{a}}$ & $* * *$ & * & NS \\
\hline Lactose & $-0.10 \pm 0.09^{c}$ & $-0.52 \pm 0.10^{\mathrm{d}}$ & $0.49 \pm 0.09^{\mathrm{a}}$ & $0.19 \pm 0.10^{\mathrm{b}}$ & $* * *$ & $* * *$ & NS \\
\hline Protein & $-0.08 \pm 0.09^{b c}$ & $-0.34 \pm 0.11^{\mathrm{c}}$ & $0.34 \pm 0.09^{\mathrm{a}}$ & $0.15 \pm 0.10^{\mathrm{ab}}$ & $* * *$ & $*$ & NS \\
\hline Fat & $0.04 \pm 0.10^{\mathrm{a}}$ & $0.06 \pm 0.11^{\mathrm{a}}$ & $0.12 \pm 0.10^{\mathrm{a}}$ & $-0.04 \pm 0.10^{\mathrm{a}}$ & NS & NS & NS \\
\hline
\end{tabular}

${ }^{\mathrm{a}-\mathrm{d}}$ Values within rows having different superscript letters differ $(P<0.05)$.

${ }^{1}$ Least squares means $\pm \mathrm{SE}$.

${ }^{2} \mathrm{~B}=$ Breed; $\mathrm{MF}=$ milking frequency.

NS $=$ Not significant; $* P<0.05 ; * * P<0.01 ; * * * P<0.001$. 
Table 3. Correlations between total yield and persistency for 3 measures of persistency of lactation (Pers1, Pers2, and Pers3) for milk, lactose, protein, and fat in Friesian and Jersey cows milked once or twice daily

\begin{tabular}{|c|c|c|c|c|c|c|}
\hline & \multicolumn{2}{|c|}{ Friesian } & \multicolumn{2}{|c|}{ Jersey } & \multirow{2}{*}{\multicolumn{2}{|c|}{ Significance $^{1}$}} \\
\hline & \multirow{2}{*}{$\begin{array}{l}\text { Once } \\
\text { daily }\end{array}$} & \multirow{2}{*}{$\begin{array}{l}\text { Twice } \\
\text { daily }\end{array}$} & \multirow{2}{*}{$\begin{array}{l}\text { Once } \\
\text { daily }\end{array}$} & \multirow{2}{*}{$\begin{array}{l}\text { Twice } \\
\text { daily }\end{array}$} & & \\
\hline & & & & & B & $\mathrm{MF}$ \\
\hline \multirow{2}{*}{\multicolumn{7}{|c|}{ Pers1 }} \\
\hline & & & & & & \\
\hline Milk & 0.03 & -0.08 & $0.35^{* * *}$ & $0.20^{*}$ & NS & NS \\
\hline Lactose & 0.04 & -0.06 & $0.35 * * *$ & $0.20^{*}$ & $\mathrm{NS}$ & NS \\
\hline Protein & 0.05 & 0.07 & $0.42 * * *$ & 0.19 & NS & NS \\
\hline Fat & 0.09 & 0.13 & $0.31 * * *$ & 0.13 & $\mathrm{NS}$ & NS \\
\hline \multicolumn{7}{|l|}{ Pers2 } \\
\hline Milk & -0.11 & -0.17 & $0.30 * * *$ & 0.16 & NS & NS \\
\hline Lactose & -0.15 & -0.16 & $0.24^{*}$ & 0.16 & $\mathrm{NS}$ & NS \\
\hline Protein & -0.12 & -0.04 & $0.33 * * *$ & 0.18 & $\mathrm{NS}$ & $*$ \\
\hline Fat & -0.02 & 0.04 & $0.26 * *$ & 0.06 & $\mathrm{NS}$ & $*$ \\
\hline \multicolumn{7}{|l|}{ Pers3 } \\
\hline Milk & $-0.38^{* * *}$ & $-0.33^{* *}$ & -0.03 & -0.19 & $\mathrm{NS}$ & NS \\
\hline Lactose & $-0.41^{* * *}$ & $-0.30^{* *}$ & -0.06 & $-0.24^{*}$ & $\mathrm{NS}$ & NS \\
\hline Protein & $-0.32^{* *}$ & $-0.23^{*}$ & 0.09 & -0.10 & $\mathrm{NS}$ & NS \\
\hline Fat & $-0.33^{* *}$ & $-0.22^{*}$ & 0.08 & $-0.27 * *$ & NS & NS \\
\hline
\end{tabular}

${ }^{1} \mathrm{~B}=$ Breed; $\mathrm{MF}=$ milking frequency.

NS = Not significant $* P<0.05 ; * * P<0.01 ; * * * P<0.001$.

\section{DISCUSSION}

Cows milked once daily had less total yields of all milk components than cows milked twice daily. The greater range in yields of the Friesians milked once daily compared with the Friesians milked twice daily indicated that some cows were capable of producing high yields when milked once daily. The large variability in total yields of the Friesians milked once daily observed in this trial was consistent with other studies (Claesson et al., 1959; Carruthers et al., 1989; Holmes et al., 1992). The nature of the trial design also contributed to the large variability in milk total yields because milk yield was not used in culling decisions. Low-yielding cows remained on test provided they were pregnant and had no health issues, because the performance of poor performers was equally as important as that of high-yielding cows when trying to determine what makes a cow suitable for once-daily milking. Milking once daily at a greater stocking rate decreased peak yields, and these peaks were reached earlier in lactation. On a per-cow basis, production of the Friesians

Table 4. Correlations between peak yield and persistency for 3 measures of persistency of lactation (Pers1, Pers2, and Pers3) for milk, lactose, protein, and fat in Friesian and Jersey cows milked once or twice daily

\begin{tabular}{|c|c|c|c|c|c|c|}
\hline & \multicolumn{2}{|c|}{ Friesian } & \multicolumn{2}{|c|}{ Jersey } & \multirow{2}{*}{\multicolumn{2}{|c|}{ Significance $^{1}$}} \\
\hline & \multirow{2}{*}{$\begin{array}{l}\text { Once } \\
\text { daily }\end{array}$} & \multirow{2}{*}{$\begin{array}{l}\text { Twice } \\
\text { daily }\end{array}$} & \multirow{2}{*}{$\begin{array}{l}\text { Once } \\
\text { daily }\end{array}$} & \multirow{2}{*}{$\begin{array}{l}\text { Twice } \\
\text { daily }\end{array}$} & & \\
\hline & & & & & B & MF \\
\hline No. of cows & 100 & 85 & 119 & 101 & & \\
\hline \multicolumn{7}{|l|}{ Pers1 } \\
\hline Milk & $-0.29 * *$ & $-0.33^{* *}$ & -0.11 & -0.02 & NS & NS \\
\hline Lactose & $-0.30 * *$ & $-0.28^{* *}$ & -0.10 & -0.02 & NS & NS \\
\hline Protein & $-0.34^{* * *}$ & $-0.28^{* *}$ & -0.09 & -0.13 & NS & NS \\
\hline Fat & $-0.32 * *$ & -0.20 & $-0.18^{*}$ & -0.14 & NS & NS \\
\hline \multicolumn{7}{|l|}{ Pers2 } \\
\hline Milk & -0.39 *** & $-0.28 * *$ & -0.14 & -0.02 & NS & NS \\
\hline Lactose & $-0.44^{* * *}$ & $-0.25^{*}$ & -0.17 & -0.02 & NS & NS \\
\hline Protein & $-0.49 * * *$ & $-0.30 * *$ & $-0.21^{*}$ & -0.18 & NS & NS \\
\hline Fat & $-0.42^{* * *}$ & $-0.27^{*}$ & $-0.23 * *$ & -0.18 & NS & NS \\
\hline \multicolumn{7}{|l|}{ Pers3 } \\
\hline Milk & $-0.78^{* * *}$ & $-0.79 * * *$ & $-0.67 * * *$ & $-0.73^{* * *}$ & NS & NS \\
\hline Lactose & $-0.81^{* * *}$ & $-0.77 * * *$ & $-0.68 * * *$ & $-0.78^{* * *}$ & NS & NS \\
\hline Protein & $-0.76^{* * *}$ & $-0.74 * * *$ & $-0.59 * * *$ & $-0.69 * * *$ & NS & NS \\
\hline Fat & $-0.75^{* * *}$ & $-0.72 * * *$ & $-0.60 * * *$ & $-0.75^{* * *}$ & NS & NS \\
\hline
\end{tabular}

${ }^{1} \mathrm{~B}=$ Breed; $\mathrm{MF}=$ milking frequency.

NS = Not significant; $* P<0.05 ; * * P<0.01 ; * * * P<0.001$. 
milked once daily was similar to that of the Jerseys milked twice daily, although the Friesians milked once daily produced more milk volume, but less fat. This is typical of the differences in fat concentration of milk between Jersey and Friesian cows (Holmes et al., 2002). Year effects were significant for total yields, and Pers3, and for Pers1 for protein and lactose yield. Differences between years most likely reflect differences in pasture availability and quality because of different climatic conditions.

Persistency of lactation refers to the ability of the cow to maintain production after peak yield (Togashi and Lin, 2003; Kamidi, 2005). Cows with flatter lactation curves have greater persistency than cows that show a large decline in production after peak. Cows that produce milk steadily throughout lactation are preferred to cows that produce large quantities of milk at peak, but little thereafter (Wood, 1967), although production of all pasture-fed cows fluctuate with pasture growth (Kamidi, 2005). Persistency is particularly important to total yield. In New Zealand's seasonal dairying system, persistent lactations are preferred to those with high peak yields as a means of achieving high production because they improve the processing efficiency of New Zealand milk. Persistency of lactation of grazing cows in New Zealand is dependent on the availability of pasture during lactation. Rate of decline in milk yield after the peak is faster in these pasturefed cows than in cows fed adequate concentrate rations. Variability in pasture growth rates during summer and fall can induce variability in the persistency of lactation (Holmes et al., 2002).

Whereas persistency is relatively easy to assess qualitatively, it is more difficult to measure quantitatively (Turner, 1925). Measures of persistency define the rate of decline in milk yield over lactation (Turner, 1925), measure relative yields for peak yield, mean daily yield, total yield, or daily yield at dry off (Bar-Anan et al., 1985; Keown et al., 1986; Murray and Brand, 2000) or evaluate the distribution of milk secretion throughout lactation (Togashi and Lin, 2003; Kamidi, 2005). The 3 persistency measures used in this study provided a selection of different measures of persistency that highlighted the importance of selecting an appropriate persistency measure.

Tendency for once-daily cows to have worse persistency than cows milked twice daily indicates that oncedaily milking at a $17 \%$ greater stocking rate does not offer a solution to the processing inefficiencies caused by the seasonality of milk supply in New Zealand. Adjusting the stocking rate may alleviate the reduction in persistency. Conversely, in the Jersey herds, production per hectare was similar between the 2 milking frequencies, indicating that the stocking rate increase was appropriate. Friesians milked once daily failed to match the Friesians milked twice daily for production per hectare, indicating that further manipulation of the stocking rate for Friesian cows milked once daily may be required. Generally, at a greater stocking rate, less feed is available per cow; hence, production per cow is less than it might have been at a lesser stocking rate. In the pastoral system, production per hectare is often the parameter to be maximized; hence, increased stocking rate (and reduced yields per cow) may be profitable (Holmes et al., 2002).

Persistency is determined by the rate of milk secretion on each day of lactation after peak. On any day, rate of milk secretion by a cow is dependent on its genetic potential for milk production and a range of environmental influences such as BW, BCS, age, health, stage of gestation, feed intake, season, temperature, and humidity (Turner, 1925; Togashi and Lin, 2003). Substantial variation in the shape of individual lactation curves has been observed within herds (Olori et al., 1999), so variation in persistency among cows is likely. In the current study, it was hypothesized that cows milked once daily would have longer lactations than those milked twice daily. Cows milked once daily gained more BW and BCS during midlactation than those milked twice daily (Woolford et al., 1985; Lynch et al., 1991; Holmes et al., 1992). This condition could be used during late lactation to support milk yield beyond that achievable with twice-daily milking. Pasturefed cows milked twice daily often must be dried off to increase BCS before their next calving. In fact, the converse was true, with cows milked once daily dried off early because of low production and high SCC. The SCC of the once-daily herds were approximately twice that of the twice-daily herds (Lacy-Hulbert et al., 2005).

Milk production at any stage of lactation is determined by the number and activity of secretory cells present (Knight and Peaker, 1984; Capuco et al., 2003; Vetharaniam et al., 2003). Numbers of secretory cells are affected by the relative rates of cell proliferation and apoptosis (Capuco et al., 2003). Secretory cells engorged with milk become quiescent until the milk is removed; hence, milking frequency affects secretory cell activity (Vetharaniam et al., 2003). The cells have a finite period for which they can remain quiescent before they begin to regress (Vetharaniam et al., 2003), and are more likely to senesce when longer intermilking intervals are imposed (Capuco et al., 2003). Davis et al. (2000) showed that reduced functional udder capacity that occurs during the latter part of lactation is largely a reduction in the alveolar capacity. This reduction in alveolar capacity may be advanced by longer intermilking intervals in cows milked once daily. Carruthers et al. (1993) found that the loss of tissue after peak was accelerated 
in Friesian cows milked once daily relative to those milked twice daily, but this effect was much less in Jerseys milked once daily. In goats, the initial decline in milk yield after peak occurred because of reduced numbers of secretory cells, but the decline in late lactation was because of decreased activity of the secretory cells (Knight and Peaker, 1984). Number and activity of secretory cells were not measured in this study, but the worse persistency of the once-daily cows was likely the result of their having lost more secretory cells, and existing cells having less secretory activity, than in the twice-daily cows.

Persistency of lactation, combined with peak yield, determines the total yield of the cow (Turner, 1925). The negative correlation that existed between persistency and peak yield in the Friesian herds explained the absence of a significant correlation between Pers1 or Pers2 and total yields in these herds, because some cows would have had high yields because of having greater persistency and others could have high yields because of having greater peak yields (but low persistency). Values for Pers1 and Pers2 were relatively similar, with the twice-daily herds tending to have greater persistency than once-daily herds, with no significant effect of breed. Values for Pers1 and Pers2 tended to follow a similar pattern to total yields, with Friesians milked twice daily having the greatest and Jerseys milked once daily having the smallest values. Correlations between persistency and total yield were present only in the Jerseys milked twice daily for Pers1 and Pers2, and were similar to the correlation of 0.37 between persistency and total milk yield found in Israeli Holsteins (Bar-Anan et al., 1985). For Pers3, however, the Jerseys milked once daily had the greatest persistency. Jerseys milked once daily had the smallest total yields, whereas Friesians milked twice daily tended to have the smallest Pers3. The negative correlations between total yield and Pers3 found in this study were consistent with others (Kamidi, 2005).

Similarities between Pers1 and Pers2 can be explained by the fact that both of these parameters measure persistency of yield after peak, whereas Pers3 is based on the rate at which total yield is attained (or deceleration of milk secretion). Claesson et al. (1959) observed greater persistency in first-lactation cows milked twice daily than in those milked once daily. This was consistent with Pers1 and Pers2 in this study. The values of $\gamma$ calculated found in the present study were smaller than those calculated by Kamidi (2005), because more of the cows in the present study had desirable, flatter lactation curves. Values of Pers1 were smaller than those presented by Turner (1925), particularly in the once-daily herds. Low persistency achieved by cows in the current study is likely due to a combina- tion of declining feed supply in the summer and fall (mid-late lactation), and the advancing stage of pregnancy.

Cows milked once daily had less production and less persistency of production than cows milked twice daily. Nevertheless, milking once daily may be a viable option for dairy producers willing to accept reduced income from milk in return for more time spent on nonmilking activities, especially when stocking rate is increased to counter the reduction in milk yield per cow. Lack of significant correlations between persistency and total yield in the once-daily herds indicate that increasing the persistency of the herd is unlikely to increase total productivity. Nevertheless, the importance of persistency to processing efficiency of milk in New Zealand shows that persistency of lactation must be considered. Some cows performed well when milked once daily, so there may be potential to select cows that are tolerant to once-daily milking and consequently improve the performance of once-daily herds.

\section{ACKNOWLEDGMENTS}

The authors are grateful to Dexcel Ltd. (Hamilton, New Zealand) for allowing the use of their data from the Dexcel Whareroa once-daily milking trial. Financial assistance for the primary author was provided by Livestock Improvement Corporation, New Zealand.

\section{REFERENCES}

Bar-Anan, R., M. Ron, and G. R. Wiggans. 1985. Associations among milk yield, yield persistency, conception, and culling of Israeli Holstein dairy cattle. J. Dairy Sci. 68:382-386.

Capuco, A. V., S. E. Ellis, S. A. Hale, E. Long, R. A. Erdman, X. Zhao, and M. J. Paape. 2003. Lactation persistency: Insights from mammary cell proliferation studies. J. Anim. Sci. 81(Suppl. 3):18-31.

Carruthers, V. R., S. R. Davis, A. M. Bryant, H. V. Henderson, C. A. Morris, and P. J. A. Copeman. 1993. Response of Jersey and Friesian cows to once a day milking and prediction of response based on udder characteristics and milk composition. J. Dairy Res. 60:1-11.

Carruthers, V. R., S. R. Davis, A. M. Bryant, and C. A. Morris. 1989. Selection of cows for once a day milking. Proc. Ruakura Farmers' Conf. Hamilton, New Zealand 41:12-14.

Claesson, O., A. Hansson, N. Gustafsson, and E. Brännäng. 1959. Studies on monozygous cattle twins. XVII: Once-a-day milking compared with twice-a-day milking. Acta Agric. Scand. 9:38-58.

Davis, S. R., V. C. Farr, M. J. Auldist, and E. S. Kolver. 2000. Effects of diet on udder function and regression in Holstein-Friesian cattle. Proc. N.Z. Soc. Anim. Prod. 60:275-276.

Davis, S. R., V. C. Farr, and K. Stelwagen. 1998. Once-daily milking of dairy cows: An appraisal. Proc. N.Z. Soc. Anim. Prod. 58:36-40.

Davis, S. R., V. C. Farr, and K. Stelwagen. 1999. Regulation of yield loss and milk composition during once-daily milking: A review. Livest. Prod. Sci. 59:74-94.

Harding, L., G. Harding, F. Harding, and R. Harding. 1990. Once daily milking throughout lactation. Dairyfarming Annu. Massey University, Palmerston North, New Zealand 42:85-87.

Harding, L., G. Harding, F. Harding, and R. Harding. 2002. Milking cows once daily since 1985: Our reasons and experiences. 
Dairyfarming Annu. Massey University, Palmerston North, New Zealand 54:105-107.

Holmes, C. W., G. F. Wilson, D. D. S. Mackenzie, and J. Purchas. 1992. The effects of milking once daily throughout lactation on the performance of dairy cows grazing on pasture. Proc. N.Z. Soc. Anim. Prod. 52:13-16.

Holmes, C. W., I. M. Brookes, D. J. Garrick, D. D. S. Mackenzie, T. J. Parkinson, and G. F. Wilson. 2002. Milk Production from Pasture: Principles and Practices. Massey University, Palmerston North, New Zealand.

Kamidi, R. E. 2005. A parametric measure of lactation persistency in dairy cattle. Livest. Prod. Sci. 96:141-148.

Keown, J. F., R. W. Everett, N. B. Empet, and L. H. Wadell. 1986 Lactation curves. J. Dairy Sci. 69:769-781.

Knight, C. H., and M. Peaker. 1984. Mammary development and regression during lactation in goats in relation to milk secretion. Q. J. Exp. Physiol. 69:331-338.

Lacy-Hulbert, S. J., D. E. Dalley, and D. A. Clark. 2005. The effects of once a day milking on mastitis and somatic cell count. Proc. N.Z. Soc. Anim. Prod. 65:137-142.

Lynch, G. A., M. E. Hunt, and D. D. S. Mackenzie. 1991. The effects of once daily milking as a management practice in late lactation. Proc. N.Z. Soc. Anim. Prod. 51:191-195.

Macdonald, K. A., and J. W. Penno. 1998. Management decision rules to optimise milksolids production on dairy farms. Proc. N.Z. Soc. Anim. Prod. 58:132-135.
Murray, B., and P. Brand. 2000. Test day model genetic evaluations for dairy production traits. Online. http://www.gov.on.ca/ OMAFRA/english/livestock/dairy/facts/info_cdn.htm. Accessed October 12, 2004.

Olori, V. E., S. Brotherstone, W. G. Hill, and B. J. McGuirk. 1999. Fit of standard models of the lactation curve to weekly records of milk production of cows in a single herd. Livest. Prod. Sci. 58:55-63.

Togashi, K., and C. Y. Lin. 2003. Modifying the lactation curve to improve lactation milk and persistency. J. Dairy Sci. 86:14871493.

Tong, M. J., D. A. Clark, and C. V. Cooper. 2002. Once-a-day milking: Possible and profitable? Proc. N.Z. Grassl. Assoc. 64:33-37.

Turner, C. W. 1925. A quantitative form of expressing persistency of milk or fat secretion. J. Dairy Sci. 9:203-214.

Vetharaniam, I., S. R. Davis, T. K. Soboleva, P. R. Shorten, and G. C. Wake. 2003. Modeling the interaction of milking frequency and nutrition on mammary gland growth and lactation. J. Dairy Sci. 86:1987-1996.

Wood, P. D. P. 1967. Algebraic model of the lactation curve in cattle. Nature 216:164-165.

Woolford, M. W., P. J. A. Copeman, A. R. Napper, D. S. M. Phillips, J. H. Williamson, and E. J. Uljee. 1985. Milking intervals: Are changes worthwhile? Proc. Ruakura Farmers'. Conf. 37:120-128. 